\title{
Sustaining the Environment: the Wisdom of Banyumas Women in Ahmad Tohari's Novels
}

\author{
Septi Yulisatiani ${ }^{1}$, Sarwiji Suwandi², Suyitno 3 , Slamet Subiyantoro ${ }^{4}$ \\ 1,2,3,4Faculty of Teacher Training and Education. Email: septiyulisetiani@gmail.com \\ 1,2,3,4Sebelas Maret University, Indonesia
}

\begin{abstract}
This article discusses the wisdom of Banyumas women in preserving the environment, as represented in the novels of Ahmad Tohari. In this study, 'Banyumas women' is the term used for women who live in the Banyumas area, central Java, Indonesia and who perform activities which preserve their environment. Research into literary works such as Ahmad Tohari's novels is important because its results can be used as guidelines for readers in choosing quality literature. This research was conducted employing an ecofeminism approach to literary texts. The research method used is qualitative content analysis and the data is drawn from six novels by Ahmad Tohari. The results of the study show that novels by Ahmad Tohari depict women who engage in activities which manage the environment wisely. These activities include wisely conducted activities in processing natural resources into food and herbal medicines, using environmentally friendly equipment in daily living, preserving domesticated animals and their habitats, and in utilizing nature as a medium and a place to play for their children. These environment-preserving activities represented in Ahmad Tohari's novels can be used as a guide for people around the world for preserving their own environments.
\end{abstract}

Keywords: Women's activities, wisdom, environment, novel, Indonesia

\section{Introduction}

One of the vital issues for humans today is the condition of the earth's environment. Environmental issues discussed in literary works have the purpose and/or effect of giving messages to readers about environmental conditions, causes of environmental damage and solutions that can be chosen to protect and preserve the environment. In real life, environmental problems afflict humans in all countries, including Indonesia. Bradshaw Giam \& Sodhi states that environmental damage has occurred in various countries such as Singapore, Korea, Qatar, Kuwait, Japan, Thailand, Bahrain, Malaysia, Philipines, Netherland, Denmark, Srilanka, Indonesia and so on [1]. Jambosorg, Pournouri, Poorhashemi, \& Hermidas categorizes environmental damage as a form of international crime [2]. Voza gives the assessment that environmental damage is a problem that occurs in the world [3].

Literary works are written by writers to respond to various problems that develop in society. These include social, cultural and humanitarian issues, psychiatric problems, women's problems, religiosity issues and environmental issues. Language issues are characterized in Jia novel [4]. Bangladesh historical facts are characterized in Niaz Saman novel [5]. Children's

(C) AesthetixMS 2020. This Open Access article is published under a Creative Commons Attribution Non-Commercial 4.0 International License (http://creativecommons.org/licenses/by-nc/4.0/), which permits non-commercial re-use, distribution, and reproduction in any medium, provided the original work is properly cited. For citation use the DOI. For commercial re-use, please contact editor@rupkatha.com. 
problems are characterized in Beruk novel [6]. Power issues are characterized in Nadine Gordmier novel [7]. Female character issues are characterized in Cinta Bertasbih novel [8].

Through their literary works, poets have a role in shaping the awareness of readers around environmental concerns. The environmental issues raised in literary works aim to give a message about the importance of humans being concerned about the environment. Among Indonesian writers who have raised environmental issues in their writing is Ayu Utami, through her novel Maya; Dewi Lestari through her novel Partikel; Laksmi Pamjutak through her novel Amba; Korie Layun Rampan through her novel Bunga; Zainal Arifin Toha through her puisi, dan Ahmad Tohari through her novels Ronggeng Dukuh Paruk, Bekisar Merah, Lingkar Tanah Lingkar Air, OrangOrang Proyek, dan Kubah.

Research has been carried out into the environmental issues raised in Maya, Partikel, Amba, Bunga. While Hidayat has researched the poems of Zainal Airifin Toha and revealed that the poem contains relations between God, humans and the universe [9]. For this reason, humans who have a transcendental awareness will become human beings who care about nature because nature is a gift from God. Another study was conducted by Dewi into contemporary Indonesian short stories. Dewi argues that Indonesian contemporary short stories contain criticism of human behaviour that exploits nature [10]. Furthermore, Thobroni has examined environmental issues represented in literature by Korie Layun Rampan [11].

Ahmad Tohari has also raised environmental issues in his novels. This research will reveal the wisdom of women in his work regarding the environment. Mcbeth and Volk see that the environment is the space occupied by a living thing with non-living things, with humans, animals, plants, soil, water and air all being aspects of the environment [12].

Novelist Ahmad Tohari and his works have become known internationally, and he has received several international awards, such as the Fellow Writer of the University of Lowa (1991); The South East Asia Writes Award, Bangkok, Thailand (1995); Etc. He has been invited to discuss his works in various countries, including at the International Writing Program, USA, in 1990; Lowa, USA, in 1991; Leiden, Belanda in 1996; Jerman, in 1997; Kuala Lumpur, in 1999; University of California Los Angeles, University of California Riverside, in 2000; Singapore in 2009; Belanda, in 2013; and Frankfurt, in 2015. Ahmad Tohari's novel Ronggeng Dukuh Paruk, Bekisar Merah, Lingkar Tanah Lingkar Air, Orang-Orang Proyek, dan Kubah as a publishing phenomenon; since its first year of publication it has been continually reprinted and has been read by many people across the world. Some of Ahmad Tohari's other novels are similarly popular, and have been translated into various languages such as Banyumas, Spanish, Chinese, Jerman, Belanda and English.

Various issues and problems in Ahmad Tohari's novels have attracted the attention of researchers. Among these are the issue of representation of Javanese culture [13]; structural problems in the novel [14]; the issue of contextualization of philosophical and prophetic culture" [15]; the issue of Banyumas culture [16]; the problem of the Chinese [17]; the problem of genetic structuralism [18]; and ethical issues of the Banyumas community [19]. This study's review of research into Ahmad Tohari's novels shows that the research into women's wisdom in preserving the environment discussed in this article is new and is therefore an important topic for investigation.

Environmental conservation can be based on understanding and applying environmental wisdom that develops in the community; knowledge of this environmental wisdom can be learned through literary media and storytelling activities. Literary works can be chosen as a medium for 
developing and strengthening the characteristic of love for the environment. Ahmad Tohari's novels contain stories about the wisdom of women living in the Banyumas region, Central Java, Indonesia. Muslihudin, Rosyadi, and Santoso mentioned that many local people Banyumas lived on agricultural. Agriculture is also more only on plantations because rice fields are very limited as a consequence of a relatively high plains area [20]. The wisdom of these women as represented in Ahmad Tohari's novels is seen in the form of their wise management and preservation of the environment. Activities which preserve the environment are part of the community's wisdom about the environment. Ahmad Tohari's novels give an important moral message regarding some of the solutions to environmental damage that occurs in the world.

Ecofeminism is an interdisciplinary theory that connects ecology and feminism. The subject of ecology refers to environmental links between human and non-human aspects and seeks to uncover functional relations between animals, plants, and humans in natural surroundings as a form of organismic unity [21, 22]. Feminism is a theory used as a basis for revealing women's portrayals and roles; it references the gender of authors and various other matters concerning the uniqueness of female leaders and their work [23, 24, 25].

Ecofeminism is characterized by the emergence of discourse indicating that women are culturally related to nature, and by a culture that develops in society that believes that women are closer to nature than men $[26,27,28]$. Ecofeminism is used as a basis for dismantling patriarchal thinking and policies that oppress nature and women. Ecofeminism is also used to reveal the roles of women in saving the environment; its aim is to recreate the "green planet earth", equality between humans and unity with the universe $[26,29,30]$. In a study of literature, ecofeminism is an interdisciplinary theory that is used as a basis for seeing the development of women's lives and their relations with living beings and the universe, as represented in literary texts [26].

The environment can be seen as the unity of all objects and living things, including human behaviour, in relation to the universe. The idea of the environment includes harmony between the natural and the human [31]. Environmental wisdom is part of culture and is a type of intelligence that can shape people's knowledge about the management and preservation of natural resources. This type of wisdom can exist in the form of life philosophy and guidelines for preserving the environment [32, 33, 34, 35]. Including the nature of activities employed in managing and preserving the environment. In this context, activities are social systems related to patterned actions generated from the community that are concrete and can be observed and documented $[36,37,38,39]$.

From these characterizations, it can be concluded that ecofeminism is a scientific discipline that can be used as a basis for literary studies to reveal the role of women in the environment. In this study, ecofeminism is used as a basis to uncover the issues found in Banyumas women's wisdom about the environment as represented in Ahmad Tohari's novels.

\section{Research Method}

This research presents qualitative research using a descriptive content analysis method. Descriptive content analysis is used to describe in detail texts, including literary texts, through interpretation that centres on their content $[40,25,41]$. The source of research data in this study are literary texts, namely the novels of Ahmad Tohari: Ronggeng Dukuh Paruk [42]; Di Kaki Bukit Cibalak [43]; Bekisar Merah [44]; Orang-Orang Proyek [45]; Kubah [46]; Lingkar Tanah Lingkar Air [47]. The data-collection technique used in this study is documentation study. According to 
Creswell documentation study is carried out by recording documents and records which relate to the research problem and purpose of the study [48]. In this study, the researcher identified data sources that discussed environmental issues, formulated the problems of women's activities in preserving the environment as important issues being discussed, understood the contents of the text, compiled analytical constructs, drew conclusions and validated research findings. The validity of the research findings was tested by theoretical triangulation and method triangulation. This study seeks to examine novels by Ahmad Tohari to uncover Banyumas women's wisdom in preserving the environment.

\section{Results and Discussion}

Humans use the environment in various ways: as a habitat for living things in which they can live and interact with other living things, and as a source of food, medicine and energy sources. Mikols states that living things have a close relationship with the natural conditions around them. Humans use the environment for their daily lives, but it is the case that some overuse their environments and as a result such exploitation causes environmental damage. Banyumas women apply activities wisely in managing and preserving the environment.

Banyumas women's wisdom towards the environment can be seen through their activities for managing and preserving the environment. They have awareness that the environment is important for human life today and for generations to come and this awareness forms a wise attitude to managing and preserving the environment. Such women's activities in managing and preserving the environment are represented in Ahmad Tohari's novels. These activities include wisely conducted activities in processing natural resources into food and herbal medicines, using environmentally friendly equipment in daily living, preserving domesticated animals and their habitats, and in utilizing nature as a medium and a place to play for their children. This table explain the wisdom of the environment and the various activities identified.

Table 1: The Wisdom of The Environment

\begin{tabular}{|c|c|}
\hline $\begin{array}{c}\text { Women's Wisdom Towards The } \\
\text { Environment }\end{array}$ & $\begin{array}{c}\text { Banyumas Women's Wisdom Towards The } \\
\text { Environment }\end{array}$ \\
\hline \multirow{4}{*}{$\begin{array}{l}\text { Women process natural resources into food } \\
\text { materials wisely }\end{array}$} & processing food from ingredients available in nature \\
\hline & $\begin{array}{l}\text { use of equipment to process food made from objects } \\
\text { available in nature }\end{array}$ \\
\hline & consuming food in moderation \\
\hline & consuming food in various ways \\
\hline \multirow{3}{*}{$\begin{array}{l}\text { Women process natural resources as herbal } \\
\text { remedies }\end{array}$} & choosing plants available in nature for medicines \\
\hline & choosing objects available in nature for treatments \\
\hline & $\begin{array}{l}\text { processing natural resources into drugs using equipment } \\
\text { available in nature }\end{array}$ \\
\hline \multirow{2}{*}{$\begin{array}{l}\text { Women use environmentally friendly living } \\
\text { equipment }\end{array}$} & choosing equipment for daily living made from plants \\
\hline & $\begin{array}{l}\text { choosing objects that are available in nature as the basic } \\
\text { ingredients for equipment for living }\end{array}$ \\
\hline \multirow{2}{*}{$\begin{array}{l}\text { Banyumas women preserve animals and their } \\
\text { habitats }\end{array}$} & maintaining livestock in the open \\
\hline & maintaining land and forests for living things \\
\hline \multirow{3}{*}{$\begin{array}{l}\text { Women use nature as a medium for play for } \\
\text { their children and as a way to learn to love the } \\
\text { environment }\end{array}$} & encouraging children to playing outdoors \\
\hline & choose games related to nature \\
\hline & making toys from natural resources \\
\hline
\end{tabular}




\section{Women process natural resources into food materials wisely}

Natural resources are part of the environment and humans make use of natural resources in order to "make ends meet". One of these ends is the fulfilment of food needs. The activity of processing natural resources as food is carried out by Banyumas female characters represented in Ahmad Tohari's novels. These include the figure of Sanis in the novel Di Kaki Bukit Cibalak, the figure of Marni in the novel Kubah, the figure of Biyung in the novel Orang-Orang Proyek, and the figure of Lasi in the novel Bekisar Merah. This table contains a description of the activities of Banyumas women in wisely processing the environment into food.

Tabel 2: The Activities of Banyumas Women in Wisely Processing The Environment

\begin{tabular}{|l|l|l|}
\hline \multirow{2}{*}{$\begin{array}{l}\text { Female Figure in } \\
\text { The Novel }\end{array}$} & \multicolumn{2}{|c|}{ Environment Preserving Activities } \\
\cline { 2 - 3 } $\begin{array}{l}\text { Sanis } \\
\text { (in the novel } \mathrm{Di} \\
\text { Kaki Bukit Cibalak) }\end{array}$ & $\begin{array}{l}\text { Brying slices of yam and fish with } \\
\text { sunlight }\end{array}$ & $\begin{array}{l}\text { utilizing sunlight to dry food such as } \\
\text { sweet potatoes, coffee, rice, fish and } \\
\text { cassava }\end{array}$ \\
\cline { 2 - 3 } & preserving fish with salt & $\begin{array}{l}\text { utilizing salt from sea water to } \\
\text { preserve fish }\end{array}$ \\
\cline { 2 - 3 } & eating a lot of sweet potatoes and fish \\
\hline $\begin{array}{l}\text { Bu Mantri (in the } \\
\text { novel Kubah) }\end{array}$ & $\begin{array}{l}\text { processing cassava as a staple food } \\
\text { substitute for rice }\end{array}$ & using stone to process coffee flour \\
\cline { 2 - 2 } & $\begin{array}{l}\text { processing coffee flour in an } \\
\text { environmentally friendly way }\end{array}$ & \\
\hline $\begin{array}{l}\text { Biyung } \\
\text { (in the novel } \\
\text { Orang-Orang } \\
\text { Proyek) }\end{array}$ & processing cassava into snacks & \\
\hline $\begin{array}{l}\text { Lasi } \\
\text { (in the novel } \\
\text { Bekisar Merah) }\end{array}$ & $\begin{array}{l}\text { processing coconut juice into brown } \\
\text { sugar }\end{array}$ & $\begin{array}{l}\text { paying attention to the weather and } \\
\text { air temperature when processing sap }\end{array}$ \\
\hline
\end{tabular}

The figure of Sanis in the novel Di Kaki Bukit Cibalak is described as having wisdom in processing foodstuffs from ingredients available in nature. She also uses equipment to process food made from objects available in nature, and is described as processing sweet potatoes and fish by drying them in sunlight. This method processes food in an environmentally friendly way, and food that is dried in the sun is tastier and healthier than those processed in other ways. The actions taken by Sanis demonstrate the act of processing food wisely. She thinks that natural resources are important for life so they must be used carefully. Humans may not consume excessive amounts of food as excess will only bring about damage to the environment.

The character of Bu Mantri in the novel Kubah is described as a woman who demonstrates wisdom in processing food ingredients. She processes food from plants using various ingredients and methods and she uses environmentally friendly equipment in her preparations. One food ingredient that is obtained is cassava. Bu Mantri choses cassava as a substitute for carbohydrates such as rice and processes food items in various ways, with, for example, cassava being roasted, boiled or fried.

On another occasion, $\mathrm{Bu}$ Mantri processes food using environmentally friendly equipment. She is described as processing coffee beans using equipment made from natural materials such as rocks and clay pans. Variations in the processing and use of food ingredients are applied by Mrs. Mantri so that her family does not become bored with processed foods. In 
addition, this varied selection of foodstuffs aims to reduce excessive consumption of one type of food. Environmentally friendly equipment is used to add flavour and maintain the environment.

The activity of processing foodstuffs is also carried out by the character Biyung who appears in the novel Orang-Orang Proyek. Biyung processes cassava is a tasty snack called klanting. The process of making klanting is very environmentally friendly: cassava is harvested from the garden, then peeled, shredded, seasoned, boiled, shaped to taste and fried. The activities carried out by Biyung show variations in food processing of plants.

In the novel Bekisar Merah, the figure of Lasi performs food-processing activities in the form of converting sap into coconut sugar, in a process that is also very natural and environmentally friendly. The process begins with harvesting coconut sap which is heated to boiling point until it thickens. It is then poured into a mould made of bamboo pieces, and after hardening it becomes coconut sugar.

There are various ways of processing natural resources used as food wisely. First, one should be wise by not consuming too much food; second, one should preserve nature wisely; third, wisdom is shown by not using chemicals that are harmful to humans and the environment; and fourth, it is wise to process food using equipment available in nature.

\section{Women process natural resources as herbal remedies}

Natural resources can be used as basic ingredients for making herbal medicines and women can process particular herbs using ingredients that are available in nature for various treatments. This knowledge can form an awareness of the importance of nature for human life. The Banyumas women represented in Ahmad Tohari's novels process nature as herbal medicines. This table shows women's activities in using nature as herbal medicines.

Tabel 3: The Women Activities Process Natural Resources as Herbal Remedies

\begin{tabular}{|c|c|c|}
\hline \multirow{2}{*}{$\begin{array}{c}\text { Female Figure in The } \\
\text { Novel }\end{array}$} & \multicolumn{2}{|c|}{ Environment Preserving Activities } \\
\hline & Biotic & Abiotic \\
\hline $\begin{array}{l}\text { Rifah } \\
\text { (in the novel Kubah) }\end{array}$ & mashing basil leaves to treat warts & \multirow{4}{*}{$\begin{array}{l}\text { drinking saltwater, } \\
\text { applying ashes and } \\
\text { bury themselves in } \\
\text { sandy soil to remove } \\
\text { toxins }\end{array}$} \\
\hline $\begin{array}{l}\text { Marni } \\
\text { (in the novel Kubah) }\end{array}$ & $\begin{array}{l}\text { mixing and applying betel leaves and spices } \\
\text { as a tooth-strengthening herbal treatment }\end{array}$ & \\
\hline $\begin{array}{l}\text { Nenek Rasus } \\
\text { (in the novel Ronggeng } \\
\text { Dukuh Paruk) }\end{array}$ & $\begin{array}{l}\text { drinking coconut water to remove toxins } \\
\text { from the body }\end{array}$ & \\
\hline $\begin{array}{l}\text { Mbok Nikem } \\
\text { (in the novel Lingkar Tanah } \\
\text { Lingkar Air) }\end{array}$ & using spices to treat wounds & \\
\hline
\end{tabular}

Medicines for diseases can be produced from ingredients derived from both the biotic and abiotic environment. The figure of Rifah in the novel Kubah treats warts on the fingers with basil plants. In addition to basil leaves, coconuts can also be used as a medicine, including as an antidote for various conditions. Treatment of people who experience food poisoning with coconut fruit is exemplified by the grandmother figure in the novel Ronggeng Dukuh Paruk. This character gave first aid by offering coconut water as an antidote to her grandchildren who had been poisoned. She also performed first aid on her grandson, who had been poisoned, by burying him in sandy soil. Thanks to her actions the grandchildren survived the poisons. 
The characters of Marni in the novel Kubah and Mbok Nikem in Lingkar Tanah Lingkar Air use spices to treat wounds and to strengthen teeth. An understanding of the aspects of the environment that can be used as a source of treatment for humans will lead to environmental awareness. As a result, people will realize that the nature must be preserved and safeguarded for the survival of humanity both now and in the future. If the environment is maintained, natural remedies will continue to be available and can be utilized by humans. The Banyumas women represented in Ahmad Tohari's novels chose plants and objects available in nature as herbal medicines and they process herbal medicines using environmentally friendly equipment.

\section{Women use environmentally friendly living equipment}

Many and varied forms of equipment are used to support human life. If such equipment is made from materials that are not environmentally friendly, this can lead to a build-up of waste in the environment. To address this issue, people making equipment for daily life need to choose from materials that are environmentally friendly, as is demonstrated by the Banyumas women represented in Ahmad Tohari's novels. This table shows the wise activities of women in using environmentally friendly equipment for living.

Table 4: The Women Activities in Using Environmentally Friendly Equipment

\begin{tabular}{|l|l|l|}
\hline \multicolumn{1}{|c|}{ Female Figure in The Novel } & \multicolumn{2}{|c|}{ Environment Preserving Activities } \\
\cline { 2 - 2 } Tini (in the novel Kubah) & \multicolumn{1}{|c|}{ Biotic } & \multicolumn{1}{c|}{ Abiotic } \\
\hline $\begin{array}{l}\text { Mbok Sum } \\
\text { (in the novel Di Kaki Bukit Cibalak) }\end{array}$ & $\begin{array}{l}\text { gathering firewood to light fires } \\
\text { animals) that are not harmful } \\
\text { as a cooking } \\
\text { furnace }\end{array}$ \\
\hline $\begin{array}{l}\text { Kinah } \\
\text { (in the novel Kubah) }\end{array}$ & Using ani-ani (rice cutter) to harvest rice \\
\hline $\begin{array}{l}\text { Lasi } \\
\text { (in the novel Bekisar Merah) }\end{array}$ & $\begin{array}{l}\text { using equipment made from bamboo } \\
\text { (including tampah/trays made of bamboo, } \\
\text { pongkor/long bumbung, bumbung, lincak }\end{array}$ & \\
\hline
\end{tabular}

The character of Tini in the novel Kubah uses several items for living made from nature, including stoves made of stone and a furnace fuelled from dried coconut-tree leaves. This type of cooking equipment is very environmentally friendly because it does not cause new waste that is difficult to recycle in the soil. The figure of Marstantang's wife is also depicted using equipment for living in the form of fallen wood to light a fire. The use of fallen wood is an effort to reduce waste and preserve trees. The figure of Mbok Sum in the novel Di Kaki Bukit Cibalak uses objects made from wood waste (known as korakan) for livestock identification. The character of Kinah in the novel Kubah uses equipment called ani-ani to harvest rice and the figure of Lasi in the novel Bekisar Merah uses equipment made from plants such as bamboo stems for seating (lincak), and used bumbung to mould sugar.

Environmentally friendly equipment for living should be used so as not to add to the environmental burden of equipment waste. The rock stoves and firewood used by female figures in Ahmad Tohari's novels can be seen metaphors symbolizing simplicity. Descriptions in novels give a message about being creative with the environment. Creative people can make things they find around them into useful objects. The Banyumas female figures in Ahmad Tohari's novels choose equipment for living made from plants and choose objects that are available in nature as the basis of equipment used in day-to-day life. 


\section{Banyumas women preserve animals and their habitats}

Animals are part of ecosystems that it is important to preserve as they have reciprocal relationships with all beings on earth. Some types of animals can help plants reproduce while others can naturally fertilize the soil. Animals can also restore land forms and enrich natural resources. Additionally, certain animals can be used by humans as food ingredients. A wise human will consume animals cautiously and without excess. This table presents the wise activities pursued in preserving the environment for animals and their habitats.

Tabel 5: Women Activities Preserve Animals and Their Habitats

\begin{tabular}{|l|l|l|}
\hline \multirow{2}{*}{$\begin{array}{c}\text { Female Figure in The } \\
\text { Novel }\end{array}$} & \multicolumn{2}{|c|}{ Environment Preserving Activities } \\
\cline { 2 - 3 } & \multicolumn{1}{|c|}{ Biotic } & \multicolumn{1}{c|}{ Abiotic } \\
\hline $\begin{array}{l}\text { Mbok Sum } \begin{array}{l}\text { (in the novel Di Kaki } \\
\text { Bukit Cibalak) }\end{array} \\
\text { herding domestic animals (buffalo) } \\
\text { in teak forests }\end{array}$ & $\begin{array}{l}\text { preserving teak forest land on } \\
\text { Cibalak hill by not converting teak } \\
\text { trees into buildings }\end{array}$ \\
\cline { 2 - 2 } & not cutting down teak trees & \\
\hline
\end{tabular}

God gifts humans the ability to think, and so they have an obligation to learn how to preserve and protect animals. Having sufficient knowledge, humans must practice such techniques and provide food and shelter that is comfortable, with the aim of promoting breeding. Banyumas women in Ahmad Tohari's novels are described as having good ethics towards domestic animals. The woman named Mbok Sum in the novel Di Kaki Bukit Cibalak has a unique way of preparing the right habitat for her buffalo by giving them freedom to enjoy the outdoors. Mbok Sum's buffalo can freely enter the teak forest to eat grass and umbut reed. Mbok Sum and residents around Cibalak hill prepare habitats for their buffalo which do not damage the hills and teak forests, providing buffalo and livestock with natural places to live. Buffalo are allowed to enjoy their habitat, cover themselves with mud in teak forests and breeding. Owners indicate possession of buffalo using an object know as a korakan.

Buffalo depicted in Di Kaki Bukit Cobalak is of course only one example of a domesticated animal. Others, such as chickens, goats and ducks, also need similar types of treatment. Through Mbok Sum's activities in preserving animals, Ahmad Tohari gives a message to readers that animals have their own habitats and that these should be places to live that are open, natural and in accordance with the characteristics of the animals' lives. Knowledge of suitable habitats can be learned from various sources.

Women use nature as a medium for play for their children and as a way to learn to love the environment

Efforts to grow the characteristics of love for the environment in children are very important, and these efforts can be pursued through play activities. Children's games involving nature can be supported by choosing nature as a place to play and choosing objects from nature as toys. This table describes the activities of managing the environment as a playing medium.

Tabel 6: The Activities of Managing The Environment as a Medium of Play

Female Figure in The Novel

Environment Preserving Activities

Biotic $\quad$ Abiotic




\begin{tabular}{|l|l|l|}
\hline $\begin{array}{l}\text { Srintil } \\
\text { (in the novel Ronggeng Dukuh } \\
\text { Paruk) }\end{array}$ & $\begin{array}{l}\text { using toys made from plants such } \\
\text { as bacang leaves and jackfruit } \\
\text { leaves }\end{array}$ & $\begin{array}{l}\text { Play in the yard with } \\
\text { moonlight }\end{array}$ \\
\cline { 2 - 2 } & playing under a jackfruit tree & \\
\hline $\begin{array}{l}\text { Rifah } \\
\text { (in the novel Kubah) }\end{array}$ & $\begin{array}{l}\text { using toys made from coconut } \\
\text { leaves }\end{array}$ & \\
\hline
\end{tabular}

The figures of Rifah in the novel Kubah and Srintil in the novel Ronggeng Dukuh Paruk are described as children who use plants as toys and play with objects made from nature. For example, coconut leaves are made into rotating propellers and Rifah is portrayed as very happy playing with them. Srintil also use coconut-tree leaves as toys in a game carried out on dry fields or under trees. Srintil uses the fallen leaves of jackfruit trees to make games.

By playing under them, children develop knowledge of the importance of preserving trees. Children will understand that trees provide playgrounds, and for this reason, should not be cut down. They will experience the beauty of nature as a fun place in which to play. With this awareness, children will have an understanding of protecting the environment.

Many children today rarely play with objects from nature and rarely play in the open on, for example, moorland, under shady trees, or at night under the moonlight. Today's children more often play games online on their devices, and such digital games reduce the intensity of interactions with peers. In addition, digital games provide little opportunity for children to be close to the environment. As a result, children cannot experience the beauty of nature or feel the pleasant harmony of playing with nature. In fact, children can be far away from nature and because they lack familiarity with it they may be a generation that does not really care about nature and the environment.

\section{Conclusion}

The novels provide evidence of Ahmad Tohari's success in conveying messages to readers about preserving the environment. He describes the beauty of nature and natural purity in human activity as well as the negative impact on human life of damage to nature. Ahmad Tohari's writing presents women leaders who have wisdom about the environment which is expressed in activities that preserve the environment. These activities appear in terms of women's efforts to preserve pets, plants and soil, which are all important elements of life. The activity of preserving livestock carried out by preparing suitable habitats for animals is related to preserving and protecting forests, hills, and the outdoors generally. The activities of processing food and medicines from nature, and using equipment for living from nature must be wisely carried out. Consuming natural resources must be balanced with efforts to renew natural resources and must not be excessive. The novels investigated provide manifestations of Ahmad Tohari's success in conveying messages to readers about preserving the environment. Ahmad Tohari describes the beauty of nature, as well as natural purity in human activity. He suggests that damage to nature has a negative impact on human life, and presents the reader with women leaders who have wisdom about the environment displayed through their environment-preserving activities and their efforts to preserve important elements of life such as domestic animals, plants and soil. 


\section{References}

C. Bradshaw, J. A. Giam, Xingli, N. S. Sodhi, (2010). "Evaluating the Relative Environmental Impact of Countries”. Plos One Research Article Journal. 16 (2), pp. 1-16.

M. Jambosorg, M. Pournaori, S. Poorhashemi, D. Hermidash, (2015). "Challengs Ahead of Codification of Environmental Crime Indices as an International Crime”. Journal of Environmental Science and Technology. 12 (11), 2015, pp. 3719-3734.

D. Voza, (2017). "Historical Polution and Long-Term Liability: A Global Challenge Needing a International Approach". Journal Environmental Law and Criminology. 6 (3), pp. 423-461.

B. P. Ean, G. S. Seong, (2015). "An Analysis of the Accuarcy of Chengyu Translation in the Novel Jia into Malay”. Kemanusiaan The Asian Journal of Humanities. 22 (1), pp. 1-26.

S. Huq, (2018). "Images of Bangladesh in Niaz Zaman's Novels". Asiatic Journal. 12 (1), pp. 9-24.

Rohayati, T. I. Marlina, Madiawati, (2018). "Perserikatan Kanak-kanak dalam Novel Beruk”. Gema Online Journal of Language Studies. 18 (1), pp. 106-121.

E. Shabanirad, M. Dadkhan, (2017). "A Foucauldian Study of Space and Power in Two Novels by Nadine Gordmie”. Gema Online Journal of Language Studies. 17 (4), pp. 113-127.

Yusoh, Aziz, (2018). "Pemerkasaan Watak Wanita dalam Filem Bernuansakan Islam: Kajian Kes "Ketika Cinta Bertasbih”. Gema Online Journal of Language Studies. 18 (1), pp.140-16o.

A. Hidayat, (2017). "Ma'rifatullah dan Kearifan Lingkungan dalam Puisi”, IBDA Jurnal Kebudayaan Islam, 10 (1), pp. 96-113.

N. Dewi, (2015). "Manusia dan Lingkungan dalam Cerpen Indonesia Kontemporer: Analisis Ekokritik Cerpen Pilihan Kompas”. Jurnal Litera, 14.2, pp. 376-391.

M. Thobroni, (2016). "Sastra dan Lingkungan Dunia Kepengarangan Korie Layun Rampan”. Proceeding International Confrence On Literature XXV, Indonesia.

W. Mcbeth, L. T. Volk, (2010). "The National Environmental Literacy Project: A Baseline Study of Middle Grade”. The Journal of Environmental Education, 41 (1), pp. 55-67.

D. Saryono, (1998). "Representasi Nilai Budaya Jawa dalam Prosa Fiksi Indonesia”. Disertasi IKIP Malang.

Hartono, Tata, (2015). "Durasi, dan Frekuensi dalam Novel Orang-Orang Proyek Karya Ahmad Tohari”. Litera Journa., 4 (1), pp. 52-62.

M. Roqib, (2009). “Konekstualisasi Filsafat dan Budaya Profetik dalam Pendidikan (Studi Karya-Karya Ahmad Tohari)". Disertasi UIN Sunan Kalijaga Yogyakarta.

I. Suhardi, (2013). "Budaya Banyumas Tak Sekedar Dialek Representasi Budaya Banyumas dalam Prosa Karya Ahmad Tohari”. Jurnal Wacana Etnik. 4. (1), pp. 37-46.

C. Woodrich, (2014). "Masalah Cina, Masalah Cinta Posisi Orang Tionghoa dalam Di Kaki Bukit Cibalak Karya Ahmad Tohari”. Jurnal Puitika. 2 (1), pp. 16-25.

D. Nurhasanah. "Strukturalisme Genetik Lucien Goldmann dalam Novel Orang-Orang Proyek Karya Ahmad Tohari". Jurnal Humaniora. 6 (1), pp. 135-146.

T. Trianton, S. Suwandi, H. J. Waluyo, K. Saddhono, (2016). "Ethic Values as the Portrayal of Banyumas Local Wisdom in The Novels of Ahmad Tohari". International Journal of Languages Education and Teaching. 4 (3), pp. 306-319.

M. Muslihudin, S. Rosyadi, J. Santoso, (2019). "Sustainable Traditional Gold-Mining Management in Banyumas, Central Java, Indonesia”. International Journal of Conservation Science. 10 (1), pp.139-148.

A. Mikols, (2014). "Environmental Attitudes and Ecological Anthropocentrism: A New Challenge in Environmental Higher Education”. Journal of Education Culture and Society. 10 (1), pp. 28-40).

L. M. Jablonski, K. Klemow, G. Puttick, (2015). "Achieving Energy and Ecological Literacies for All: Linking Ecology and Energy Education. Perspectives from Sessions at Ecological Society of America (ESA) 2014 Annual Meeting. Journal of Sustainability Education. 8 (1), pp. 21-41.

S. E. Wieringa, (2010). "Penghancuran Gerakan Perempuan, Buku Kita, Yogyakarta".

S. Endraswara, (2016). "Metodologi Penelitian Ekologi Sastra, Caps, Yogyakarta".

I. N. K. Ratna, (2010). "Sastra dan Cultural Studies, Pustaka Pelajar, Yogyakarta".

R. P. Tong, (1998). "Feminist Thought: A More Comprehensif Introduction, Westview, Colorado".

S. Buckingham, (2004). "Ecofeminism in The Twenty-First Century". The Geographical Journal. 170 (2), pp. 112-119. 
S. S. Raj, M. Davidson, (2014). "Ecofeminism: The Pragmatic Posture of Feminism in 21st Century". International Journal on Studies in English Language and Literature, 2 (8), pp. 1-6.

V. Shiva, M. Mies, (1993). "Ecofeminism, Zed, London".

V. Shiva, (1997). "Perempuan Ekologi dan Perjuangan Hidup di India”. Terj. Kelik Ismanto, Yayasan Obor Indonesia, Jakarta.

W. Mcbeth, L. T. Volk, (2010). "The National Environmental Literacy Project: A Baseline Study of Middle Grade". The Journal of Environmental Education, 41 (1), pp. 55-67.

C. Beckford, N. Williams, R. Nahdee, (2010). "Aboriginal Environmental Wisdom, Stewardship, and Sustainability: Lessons From the Walpole Island First Nations, Ontario, Canada”. The Journal Of Environmental Education, 41 (4), pp. 239-248.

T. W. Fahrianoor, Taharuddin, R. Mar'i, Maryono, (2013). “The Practice Local Wisdom of Dayak People in Forest Conservation in South Kalimantan". Indonesian Journal of Wetlands Environmental Management, 10 (1), pp. 37-46.

H. Thamrin, (2014). "Kearifan Lokal dalam Pelestarian Lingkungan (The Lokal Wisdom in Environmental Sustainable)". Jurnal Kutubhanah, 16 (1), pp. 46-59.

E. M. Jayadi, Soemarno, B. Yanuwiadi, M. Purnomo, (2014). "Revitalization Local Wisdom of Wetu Teli Community in Forest Management of Bayan, North Lombok, West Nusa Tenggara”. Journal of Biodiversity and Environmental Sciences, 4 (4), pp. 384-397.

Koentjaraningrat. (2011). Pengantar Antropologi, Rineka Cipta, Jakarta.

E. Sedyawati, (2006). "Budaya Indonesia: Kajian Arkeologi Seni dan Sejarah, Raja Grafindo, Jakarta”.

H. A. Hasyim, Dardiri, Y. Hartono, (2018). "Pendidikan Multikultural di Sekolah, UNS Press, Surakarta".

S. Pamungkas, (2012). "Bahasa Indonesia dalam Berbagai Perspektif, Andi, Yogyakarta".

K. Krippendorff, (2004). "Content Analysis: An Introduction to Its Methodology, Sage Publication, Thousand Oaks".

Eriyanto, (2015). "Analisis Isi, Kencana, Jakarta”.

A. Tohari, (2016). "Ronggeng Dukuh Paruk, Gramedia, Jakarta".

A. Tohari, (2015). "Di Kaki Bukit Cibalak, Gramedia, Jakarta”.

A. Tohari, (2016). "Bekisar Merah, Gramedia, Jakarta".

A. Tohari, (2016). "Orang-Orang Proyek, Gramedia, Jakarta”.

A. Tohari, (2017). "Kubah, Gramedia, Jakarta”.

A. Tohari, (2015). "Lingkar Tanah Lingkar Air, Gramedia, Jakarta".

J. W. Creswell, (2014). "Research Design: Qualitative, Quantitative, and Mixed Methods Approaches. Sage Publication, Los Angeles". 